\title{
Seagrass ecosystems of India as bioindicators of trace elements
}

\author{
${ }^{1}$ Amrit Kumar Mishra, ${ }^{2}$ Rajalaxmi Sahoo, ${ }^{3}$ Saumya S. Samantaray ${ }^{1}$ Deepak Apte \\ ${ }^{1}$ Marine Conservation Department, Bombay Natural History Society, Hornbill House, Dr. \\ Salim Ali Chowk, Shaheed Bhagat Singh Road, Opp. Lion Gate, Mumbai, 400001, India \\ ${ }^{2}$ Department of Botany, Bangalore University, Bengaluru, 560056, Karnataka \\ ${ }^{3}$ National Institute of Science Education and Research, Homi Bhaba National Institute, Jatni- \\ 752050, Khorda, Odisha
}

Corresponding author: a.mishra@bnhs.org

\begin{abstract}
Seagrasses are considered as efficient bioindicators of coastal trace element contamination. This chapter provides an overview on the trace element accumulation, tolerance and biomonitoring capacity of the various seagrass species distributed along the coast of India. A total of 10 trace elements are reported in seagrasses, 11 in sediment and nine in the water column from India. From the 11 seagrass species studied, $60 \%$ of research have focused on Syringodium isoetifolium, Cymodocea serrulata, Cymodocea rotundata and Halophila ovalis. $78 \%$ of seagrass trace element research in India is from Palk bay and Gulf of Mannar (GOM), Tamil Nadu and $16 \%$ from Lakshadweep Islands. Out of the 10 trace elements, $\mathrm{Cd}, \mathrm{Cu}, \mathrm{Pb}$ and $\mathrm{Zn}$ are the most studied in seagrass, $\mathrm{Fe}, \mathrm{Mn}, \mathrm{Ni}$ and $\mathrm{Pb}$ in sediment and $\mathrm{Cu}, \mathrm{Fe}, \mathrm{Mg}, \mathrm{Ni}$ and $\mathrm{Zn}$ in the water column. Accumulation capacity of various trace elements in seagrass were speciesspecific. S. isoetifolium have the highest concentration of $\mathrm{Cd}$ and $\mathrm{Mg}$ at Palk bay and Lakshadweep Islands respectively. The concentration of $\mathrm{Cu}$ was higher in C. serrulata at GOM. Halodule uninervis and Halophila decipens have the highest concentration of Co, and $\mathrm{Cr}, \mathrm{Ni}, \mathrm{Pb}$ and $\mathrm{Zn}$ from Lakshadweep Islands. The highest concentration of Fe and $\mathrm{Mn}$ were highest in Halophila beccarii and $H$. ovalis from the coast of Goa and Palk bay respectively. Threshold levels ( $\left.>10 \mathrm{mg} \mathrm{L}^{-1}\right)$ of $\mathrm{Cd}, \mathrm{Cu}, \mathrm{Pb}$ and $\mathrm{Zn}$ were observed for C. serrulata, H. ovalis, $H$. uninervis and T. hemprichii, that can affect the Photo System -II of these seagrasses and exert cellular stress leading to seagrass loss and die-off. High concentration of these elements can exert negative impacts on seagrass associated trophic assemblages and ecosystem functioning. Seagrasses of India can be utilized as bioindicators of coastal trace element contamination but the associated toxicity and human health risks needs further investigation.
\end{abstract}

Keywords: seagrass, trace metals, coastal ecosystems, Anthropogenic pollution, bioindicators 


\section{Introduction}

Seagrass ecosystems are distributed worldwide covering the five important bioregions of the world oceans except Antarctica (Hemminga and Duarte, 2002; McKenzie, 2020). Seagrasses form complex interlinkage between saltmarsh and mangrove ecosystems that are important in maintaining a wide range of ecological functions (Medina-Gómez, 2016; Mishra and Apte, 2020). This inter-linkage forms complex food webs that support both herbivore grazing and detrital food chain and provides habitat and nursery for various species (Unsworth and Cullen-unsworth, 2018). Seagrasses provide 24 different types of ecosystem services (Nordlund et al., 2016), which includes habitat and nurseries for commercially important fish population and endangered sea cows (Unsworth et al. 2018), carbon sequestration and storage ((Duarte et al., 2013), shore line protection from storm surges and prevention of coastal erosion (Ondiviela et al., 2014; Potouroglou et al., 2017) and regulation of nutrient cycles (Costanza et al., 2017) that are critical in the functioning of seagrass dependent trophic levels. These ecosystem services support millions of coastal communities by supplying livelihood and food security (Nordlund et al., 2018; Unsworth et al., 2017). Like coral reefs seagrass ecosystems are also declining worldwide (Waycott et al., 2009) due to various anthropogenic factors, but the most relevant factors include habitat modification, dredging, wastewater discharge, nutrient enrichment, fishing, coastal developmental activities and boat anchoring (Lewis and Richard, 2009). These various anthropogenic activities act as a source of various anthropogenic chemicals and trace elements that enters into the marine ecosystem (Machowski et al., 2019; Serrano et al., 2011).

Trace elements as the name suggests, occurs in very low concentrations in the marine environment. At these low levels, trace elements are not toxic and play a critical role in marine ecosystem functioning (Avelar et al., 2013; Mishra et al., 2019). Among these trace elements some are non-essential and toxic to organisms ( $\mathrm{As}, \mathrm{Cd}, \mathrm{Cr}, \mathrm{Hg}$ and $\mathrm{Pb}$ ), whereas others act as essential micronutrients $(\mathrm{Cu}, \mathrm{Mn}$ and $\mathrm{Zn})$, provided that their concentrations do not exceed the threshold levels (Millero et al., 2009; Stockdale et al., 2016). These trace elements pose serious risk to seagrass eco-physiology, because of their persistent nature in the marine sediment. Once accumulated in the seagrass roots their bioavailability increases (Bonanno and Borg, 2018; Govers, 2014) and under future ocean acidification and anthropogenic pollution scenarios their concentration and toxicity is predicted to increase (Mishra et al., 2019; Vizzini et al., 2013). Once bioavailability increases, trace elements get absorbed into the root plasmalemma at the root: soil interface and are translocated to the leaves via rhizomes. Once threshold levels of trace elements are reached, it affects both root cellular structure and plant photosynthesis (Ambo-rappe et al., 2011; Prange and Dennison, 2000). Consequently, once concentrated in the seagrass tissues, through bioaccumulation these trace elements can move up the food chain through seagrass associated organisms and get biomagnified at higher trophic levels (Roberts et al., 2008; Vizzini et al., 2013) and pose serious risk for humans through marine food intake.

This chapter aims to provide state of the art information about trace element concentration in the seagrass ecosystems of India and their bioindicator potential. In the early 1990's, studies on trace element accumulation patterns in seagrasses of India started, when Jagtap, (1983) first reported about the trace element levels in the seagrass Halophila beccarii. Thereafter, in the last few decades considerable amount of data have been generated on trace elements in various seagrass species of India (Govindasamy and Arulpriya, 2011; Nobi et al., 2010; Sachithanandam et al., 2020; Sudharsan et al., 2012a; Thangaradjou et al., 2013). However, these studies have focused on few locations of India; mostly in the Palk bay and Gulf of Mannar (GOM) region of Tamil Nadu and the islands of Lakshadweep and Andaman and Nicobar, even though seagrasses have a pan India distribution. These studies have mostly 
recorded the trace element levels in water-seagrass or sediment-seagrass or seagrass only without focusing on accumulation capacity or seagrass bioindicator potential.

\subsection{Distribution and ecology of Indian Seagrasses}

Seagrass ecosystems, has a pan India distribution covering both the west and the east coast, including the islands of Andaman and Nicobar and Lakshadweep (Fig.1). These seagrass ecosystems of India are also part of South Asia (including other countries such as Pakistan, SriLanka, Bangladesh and Maldives) and South-East Asia [due to Andaman and Nicobar Islands (ANI)] in the Indian Ocean region (Fortes et al, 2018; Patro et al, 2017)India has a record of 16 seagrass species belonging to three families, i.e., Hydrocharitaceae, Cymodoceaceae and Ruppiaceae. These 16 seagrass species are part of the 19 seagrass species found in South-east Asia (Prathep et al., 2011). These 16 seagrass species of India cover an area of $516.59 \mathrm{Km}^{2}$ up to a depth limit of $21 \mathrm{~m}$ (Bayyana et al., 2020; Geevarghese et al., 2018).

These various seagrass species of India occupy sandy, muddy or mixed habitat, in the intertidal region to increased depth (Parthasarathy et al., 1991). For example, small seagrass species like Halophila beccarii, Halophila ovalis are found in the muddy or sandy-muddy habitat of the intertidal region (Parthasarathy et al., 1991), whereas other seagrass species like Thalassia hemprichii and H. beccarii are found associated with mangroves (Jagtap et al., 2003; Mishra and Apte, 2020; Mishra and Mohanraju, 2018). Consequently, bigger seagrass plants like Enhalus acoroides are found at increased depths ( Patankar et al, 2018). However, this distribution of seagrass plants is dependent upon various limiting factors such as turbidity, light penetration, nutrient availability (Arumugam et al., 2013) that affect seagrass photo-physiology and reproductive processes (Patankar et al., 2018; Mishra and Apte, 2020b). Secondly, this distribution of seagrass species is also influenced by presence of other seagrasses or mangroves or coral reefs that determines distribution patterns and ecological connectivity with sourrounding ecosystems (Apte et al., 2016; Mishra and Apte, 2020).

The presence of various seagrass species at the land and sea-interface makes them suitable bioindicators of coastal metal contamination (Bonanno and Borg, 2018; Mishra et al., 2019). This suitability of seagrass as bioindicators have been extensively used by the European Water Framework Directive using the endemic seagrass Posidonia oceanica and Cymodocea nodosa of the Mediterranean Sea (Bonanno and di Martino, 2016; Bonanno and OrlandoBonaca, 2018; Bonanno and Raccuia, 2018). However, in India there are few studies exploring the potential of seagrass as bioindicator of coastal pollution (Gopi et al., 2020; Govindasamy and Azariah, 1999; Sudharsan et al., 2012b). This chapter will provide valuable information about the various metal studies that have been carried out using different seagrass species, the efficiency of seagrass in accumulating trace elements, toxic effects of these trace elements on seagrass physiology above the threshold levels and the bioindicator potential of seagrass to these trace elements. 


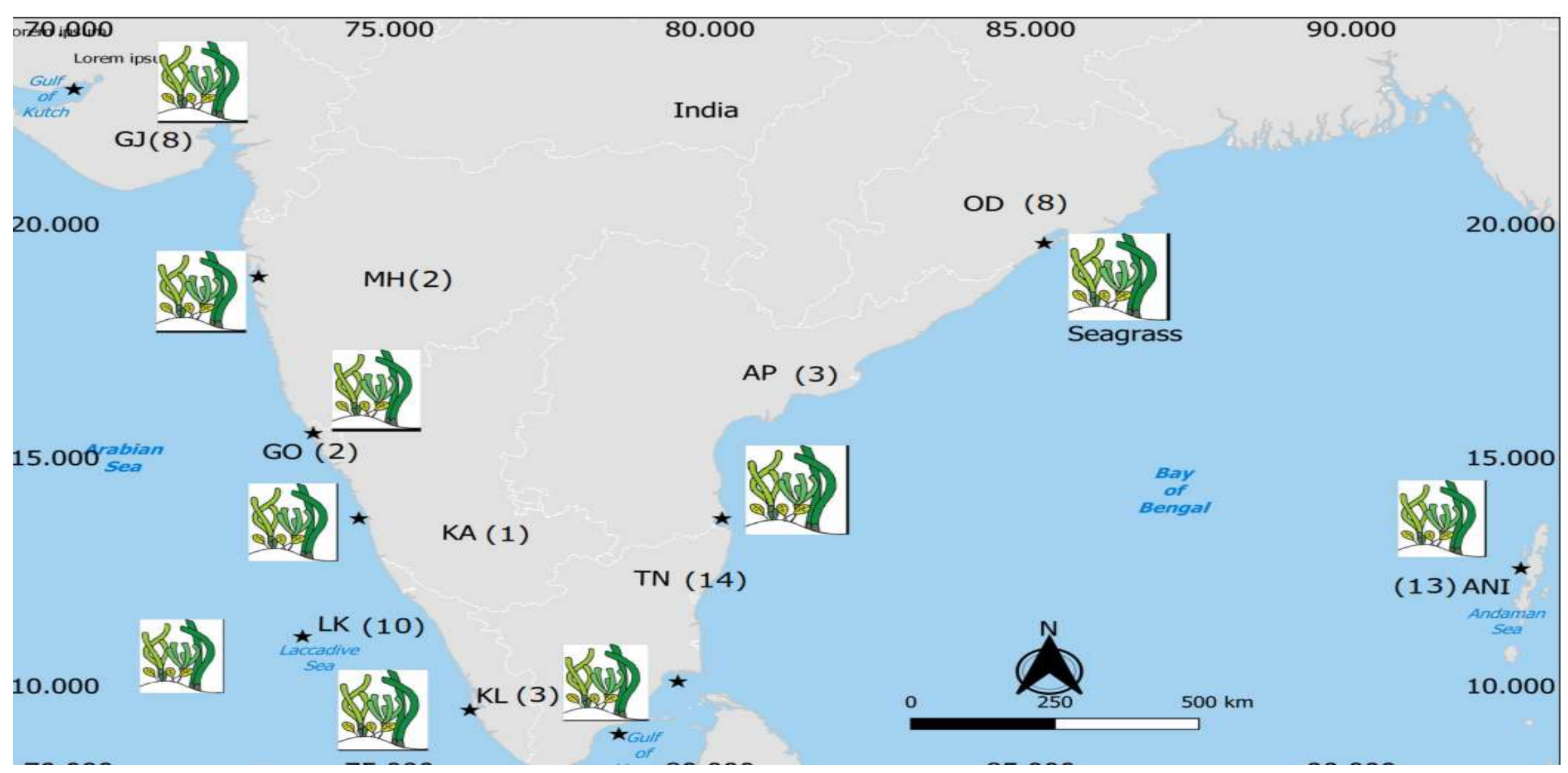

Fig.1. Map showing the States and islands that have seagrass ecosystems around the east and west coast of India. Numbers in bracket for each state indicate the number of seagrass species found in that state. Odisha (OD), Andhra Pradesh (AP), Andaman and Nicobar Islands (ANI), Tamil Nadu (TN), Kerala (KL), Lakshadweep island (LK)*, Karnataka (KA), Goa (GO), Maharashtra (MH), Gujarat (GJ). 


\section{Trace element in coastal water, sediment and seagrasses}

\subsection{Trace element in water column above seagrass meadows}

In general, it is thought that the trace element concentration is higher in the water column and readily available for the leaves of the seagrass for uptake. However, it has been observed, that is not the case always (Bonanno and di Martino, 2017). The accumulation of trace elements from the water column is species-specific among seagrasses and depends on the plant physiology and the nature of the trace element, i.e., toxic or essential (Millero et al., 2009; Mishra et al., 2019). In India, the trace element studies of the water column above seagrass ecosystems are very less compared to that of the sediment and seagrasses. Only 4 studies have reported the nine out of 11 elements ( $\mathrm{As}, \mathrm{Cd}, \mathrm{Co}, \mathrm{Cr}, \mathrm{Cu}, \mathrm{Fe}, \mathrm{Mg}, \mathrm{Mn}, \mathrm{Ni}, \mathrm{Pb}, \mathrm{Zn}$ ) reported in sediment and 10 in seagrass. However, on the west coast trace elements like $\mathrm{Cd}, \mathrm{Cr}, \mathrm{Pb}$ and $\mathrm{Zn}$ are not reported (Table 1). These studies on trace elements are restricted to five locations, i.e., Palk bay and GOM, Tamil Nadu, Goa, Maharashtra, and Lakshadweep Islands, consisting of only eight seagrass species.

Out of the nine trace elements, $\mathrm{Mg}$ was the most studied trace element in the water column of seagrass ecosystems in India, and Mn the least (Fig.2a). The concentration of $\mathrm{Mg}$ in the water column was highest in the seagrass meadows of Cymodocea rotundata, Syringodium isoetifolium, Halodule uninervis, Thalassia hemprichii and Halophila ovalis of Lakshadweep Islands. The concentration of $\mathrm{Fe}$ and $\mathrm{Mn}$ was highest in Halophila beccarii from the west coast in Goa. The water column above T. hemprichii meadows have higher concentration of $\mathrm{Cd}$ and $\mathrm{Pb}$ in Palk bay, whereas the water above $S$. isoetifolium meadows have higher concentration of $\mathrm{Cu}$ and similar levels of $\mathrm{Pb}$ with $T$. hemprichii (Table 1). The concentration of $\mathrm{Cr}, \mathrm{Ni}$ and $\mathrm{Zn}$ was similar among the water column of Cymodocea serrulata, S. isoetifolium and Enhalus acoroides meadows at GOM. The trace element concentration in the water column of various seagrasses followed a decreasing pattern, $\mathrm{Mg}>\mathrm{Zn}>\mathrm{Fe}>\mathrm{Cr}>\mathrm{Cu}>>\mathrm{Mn}>\mathrm{Ni}>\mathrm{Pb}>\mathrm{Cd}$ (Table 1). In the water column, $\mathrm{Mg}$ concentration was very low on the east coast withing a range of 0.16 to $2.06 \mathrm{mg} \mathrm{kg}^{-1}$, while that on the west coast was 550-fold higher (Table 1). The Mg concentration $\left(18318 \mathrm{mg} \mathrm{kg}^{-1}\right)$ in the water column of Lakshadweep Islands was highest in the coastal waters of India. The Zn levels were in the range of 0.11 to $11.6 \mathrm{mg} \mathrm{kg}^{-1}$, with higher levels in the water column of GOM, Tamil Nadu. The Cd concentration were in the range of 0.02 to $0.15 \mathrm{mg} \mathrm{kg}$ ${ }^{1}$, while that of $\mathrm{Cr}$ are 0.31 to $2.03 \mathrm{mg} \mathrm{kg}^{-1}$ on the east coast. Copper levels in the water column were 2-fold higher in the east coast than that of the west coast. Iron concentration were higher in the coastal waters of Goa. Manganese and Ni levels were similar among the both coasts. The concentration of $\mathrm{Pb}$ were 0.007 to $0.13 \mathrm{mg} \mathrm{kg}^{-1}$ and that of $\mathrm{Zn}$ were 0.11 to $11.6 \mathrm{mg} \mathrm{kg}^{-1}$ (Table 1). Trace elements such as $\mathrm{Co}$ and $\mathrm{Hg}$ are not reported in the water column, even though they are reported from the sediment and seagrass tissues (Fig.2b and c).

The source of trace element in the coastal waters of India are mostly through riverine input, which varies according to the monsoon dependent seasonal runoff and subsequent erosion from river catchment area (Tripathy et al., 2014). Consequently, local anthropogenic discharge from industrial and domestic waste water also leads to input of these trace elements into the coastal waters (Libin Baby et al, 2017; Nobi et al., 2010; Thangaradjou et al., 2009; Thangaradjou and Bhatt, 2018). Other than these inputs, release of trace elements from the sediment to the water column within the seagrass ecosystems also plays an important role in varying concentration of trace elements in the water column (Govindasamy and Azariah, 1999; Libin Baby et al., 2017). The low concentration of most of the elements like $\mathrm{Cd}, \mathrm{Cr}, \mathrm{Cu}, \mathrm{Ni}$ and $\mathrm{Pb}$ is a result of settling of the organic matter content that inflows with the land run-off. Seagrass ecosystems are considered as efficient ecosystem engineers and they help in settling a small fraction of this organic matter content on their leaf surface or into the sediment, thus 
reducing water turbidity and enhancing their photosynthetic activity (Gillis et al., 2017; Guannel et al., 2016). This seasonal and local variation of input of trace elements are reflected in seagrass ecosystems (Govindasamy and Azariah, 1999). This seasonal influence of high concentration of $\mathrm{Co}, \mathrm{Cd}, \mathrm{Cu}, \mathrm{Fe}, \mathrm{Ni}, \mathrm{Mn}$ and $\mathrm{Zn}$ in the water column has been observed at GOM, TN (Govindasamy and Azariah, 1999) and the east coast of India (Vinithkumar et al., 1999).

\subsection{Trace metals in the sediment of seagrass meadows}

A total of 11 trace elements has been reported in the sediment of seagrass meadows of India, including As and $\mathrm{Co}$ that has not been reported in the water column of seagrass meadows (Fig.2b). In sediment, the trace element concentration of $\mathrm{Cd}, \mathrm{Cr}, \mathrm{Cu}, \mathrm{Fe}, \mathrm{Mn}, \mathrm{Ni}, \mathrm{Pb}$ and $\mathrm{Zn}$ were multifold higher than their water column values, except $\mathrm{Mg}$ which was higher in the water column (Untawale and Jagtap, 1984). The concentration of trace elements in the sediment of seagrass meadows followed the decreasing pattern of $\mathrm{Fe}>\mathrm{Mg}>\mathrm{Mn}>\mathrm{Cr}>$ $\mathrm{Ni}>\mathrm{Cu}>\mathrm{Zn}>\mathrm{Co}>\mathrm{As}>\mathrm{Pb}>\mathrm{Cd}$ (Table 2).

Five locations of India on both the east and west coast within seagrass meadows have been used for trace element studies, i.e., Palk bay and GOM, Tamil Nadu, Goa, Maharashtra, Lakshadweep and Andaman and Nicobar Islands (ANI). The sediment of seven seagrass species, such as $S$. isoetifolium, $T$. hemprichii, C. serrulata, C. rotundata, H. beccarii, H. ovalis, H. uninervis have been used for trace element studies (Govindasamy and Azariah, 1999; Jagtap, 1983; Libin Baby et al., 2017; Thangaradjou et al., 2013; Untawale and Jagtap, 1984; Vinithkumar et al., 1999). On the east coast the sediment within seagrass meadows of GOM had higher levels of As than the seagrass sediment of Palk bay region of Tamil Nadu (Table 2). However, the highest concentration of As in the sediment of seagrass meadows were recorded from ANI. This higher concentration of As can be due to the volcanic origin of this island, where As enters the coastal ecosystem through seasonal land run-off, as these islands are far from industrially polluted (Nobi et al., 2010; Sachithanandam et al., 2020). Other than Arsenic, $\mathrm{Co}, \mathrm{Cr}, \mathrm{Cu}, \mathrm{Mg}, \mathrm{Mn}, \mathrm{Ni}$ and $\mathrm{Pb}$ concentration in the sediment of seagrass meadows are the highest in ANI (Table 2). The concentration of Fe in the sediment were higher on the west coast at Vijayagiri and Ratnagiri of Maharashtra within the $H$. beccarii meadows (Table 2 ). However, these Fe values in the sediment of $H$. beccarii are more than three decades old and this high concentration of Fe in $H$. beccarii sediment compared to other seagrass ecosystem of India can be due to its presence within close proximity of mangrove sediments, which act as sink of trace elements (Apte et al., 2016; Mishra and Kumar, 2020). Though most of the trace element levels in the sediment of $S$. isoetifolium, $T$. hemprichii and $C$. serrulata meadows of Palk bay have similar levels in their sediment (Govindasamy et al., 2013; Libin Baby et al., 2017; Thangaradjou et al., 2013) the concentration of $\mathrm{Cu}$ and $\mathrm{Zn}$ are 20-fold lower in the sediment of $T$. hemprichii meadows (Jagtap and Untawale, 1984). On the west coast, the sediment of $H$. beccarii meadows were found with high levels of $\mathrm{Cu}$ at Vijayagiri and Ratnagiri, Maharashtra(Jagtap, 1983). There is a clear evidence that the sediment of seagrass meadows act as a sink of various trace elements. Consequently, the continuous persistence of these trace elements (particularly trace elements like $\mathrm{As}, \mathrm{Cu}, \mathrm{Pb}$ ) can result in potential toxicity to seagrass rhizosphere and the seagrass associated biota (Ambo-rappe et al., 2011; Richir, 2016; Richir and Gobert, 2014). However, for the trace elements to be toxic, it has to be bioavailable to the seagrass root systems and reach above threshold levels. This bioavailability depends on trace elements mobility in the sediment, their chemical speciation (Usero et al., 2005) and sediment characteristics such as $\mathrm{pH}$, organic matter content and redox potential (Yang and Ye, 2009). 
Table 1. Mean or range of trace element concentration $(\mathrm{ppb})$ in marine water associated with various seagrass species of India. Gulf of Mannar (GOM), Tamil Nadu (TN); Maharashtra (MH); Lakshadweep island (LK)

\begin{tabular}{|c|c|c|c|c|c|c|c|c|c|c|c|}
\hline \multirow[t]{2}{*}{ Seagrass } & \multirow[t]{2}{*}{ Location } & \multirow[b]{2}{*}{ Cd } & \multirow[b]{2}{*}{$\mathrm{Cr}$} & \multirow[b]{2}{*}{$\mathbf{C u}$} & \multicolumn{2}{|c|}{ Trace elements } & \multirow[b]{2}{*}{ Mn } & \multirow[b]{2}{*}{$\mathbf{N i}$} & \multirow[b]{2}{*}{$\mathbf{P b}$} & \multirow[b]{2}{*}{$\mathbf{Z n}$} & \multirow[t]{2}{*}{ Ref. } \\
\hline & & & & & $\mathrm{Fe}$ & Mg & & & & & \\
\hline C. rotundata & $\begin{array}{l}\text { Palk bay, } \\
\text { TN }\end{array}$ & - & - & - & $0.12-0.31$ & - & - & - & - & - & $\mathrm{a}$ \\
\hline C. serrulata & $\begin{array}{l}\text { Palk bay, } \\
\text { TN }\end{array}$ & $0.09-0.11$ & $0.31-0.67$ & $0.50-1.02$ & $0.12-1.02$ & $0.28-0.33$ & $0.57-0.89$ & $0.19-0.37$ & $0.01-0.12$ & $0.11-6.38$ & $a, b$ \\
\hline S. isoetifolium & $\begin{array}{l}\text { Palk bay, } \\
\text { TN }\end{array}$ & $0.09-0.12$ & $0.31-0.67$ & $0.32-1.12$ & $0.19-0.37$ & $0.28-0.35$ & - & $0.20-0.39$ & $0.01-0.13$ & $2.06-6.38$ & $\mathrm{~b}$ \\
\hline T. hemprichii & $\begin{array}{l}\text { Palk bay, } \\
\text { TN }\end{array}$ & $0.10-0.15$ & $0.31-0.67$ & $0.32-1.02$ & $0.19-0.37$ & $0.28-0.33$ & - & $0.20-0.39$ & $0.01-0.13$ & $2.06-6.38$ & $\mathrm{~b}$ \\
\hline C. serrulata & GOM, TN & $0.02-0.06$ & $0.26-2.03$ & 0.117 & $4.60-5.30$ & $0.16-2.06$ & - & $0.22-0.56$ & 0.007 & $4.74-11.6$ & $\mathrm{~b}$ \\
\hline E. acoroides & GOM, TN & $0.02-0.06$ & $0.26-2.03$ & 0.117 & $4.60-5.30$ & $0.16-2.06$ & - & $0.22-0.56$ & 0.007 & $4.74-11.6$ & $\mathrm{~b}$ \\
\hline S. isoetifolium & GOM, TN & $0.02-0.06$ & $0.26-2.03$ & 0.117 & $4.60-5.30$ & $0.16-2.06$ & - & $0.22-0.56$ & 0.007 & $4.74-11.6$ & $\mathrm{~b}$ \\
\hline H. beccarii & Goa & - & - & 0.42 & 7.4 & 614 & 0.76 & 0.22 & - & - & $\mathrm{c}$ \\
\hline H. beccarii & $\begin{array}{l}\text { Malvan, } \\
\mathrm{MH}\end{array}$ & - & - & 0.32 & 1.05 & 990 & 0.18 & 0.46 & - & - & $\mathrm{c}$ \\
\hline H. beccarii & $\begin{array}{l}\text { Vijayagiri, } \\
\mathrm{MH}\end{array}$ & - & - & 0.27 & 2.75 & 774 & 0.17 & 0.30 & - & - & $\mathrm{c}$ \\
\hline H. beccarii & $\begin{array}{l}\text { Ratnagiri, } \\
\mathrm{MH}\end{array}$ & - & - & 0.19 & 0.55 & 1100 & 0.09 & 0.54 & - & - & $\mathrm{c}$ \\
\hline C. rotundata & LK & - & - & - & - & 18318 & - & - & - & - & $\mathrm{d}$ \\
\hline S. isoetifolium & LK & - & - & - & - & 18317 & - & - & - & - & $\mathrm{d}$ \\
\hline H. uninervis & LK & - & - & - & - & 18318 & - & - & - & - & $\mathrm{d}$ \\
\hline T. hemprichii & LK & - & - & - & - & 18318 & - & - & - & - & $\mathrm{d}$ \\
\hline H. ovalis & LK & - & - & - & - & 18318 & - & - & - & - & $\mathrm{d}$ \\
\hline
\end{tabular}

a) Govindasamy et al. 2011, b) Baby et al. 2017, c) Jagtap, 1983, d) Jagtap and Untawale, 1984 
Table 2. Mean or range of trace element concentration $(\mathrm{mg} / \mathrm{kg})$ in sediment associated with various seagrass species of India. Gulf of Mannar (GOM), Tamil Nadu (TN); Maharashtra (MH); Lakshadweep island (LK), Andaman and Nicobar Islands (ANI)

\begin{tabular}{|c|c|c|c|c|c|c|c|c|c|c|c|c|c|}
\hline \multirow[t]{2}{*}{ Seagrass } & \multirow[t]{2}{*}{ Loc. } & \multirow[b]{2}{*}{ As } & \multirow[b]{2}{*}{ Cd } & \multirow[b]{2}{*}{ Co } & \multirow[b]{2}{*}{$\mathbf{C r}$} & \multirow[b]{2}{*}{$\mathbf{C u}$} & \multicolumn{2}{|c|}{ Trace elements } & \multirow[b]{2}{*}{ Mn } & \multirow[b]{2}{*}{$\mathbf{N i}$} & \multirow[b]{2}{*}{$\mathbf{P b}$} & \multirow[b]{2}{*}{ Zn } & \multirow[t]{2}{*}{ Ref. } \\
\hline & & & & & & & Fe & Mg & & & & & \\
\hline C. serrulata & Palk bay, TN & 3.28 & $\begin{array}{l}0.23- \\
0.27\end{array}$ & - & $\begin{array}{l}4.81- \\
4.92\end{array}$ & $\begin{array}{l}1.55- \\
45.5\end{array}$ & $\begin{array}{l}16.5- \\
1040\end{array}$ & 42 & $\begin{array}{l}29.4- \\
64.8\end{array}$ & $\begin{array}{l}1.22- \\
1.41\end{array}$ & $\begin{array}{l}0.61- \\
0.81\end{array}$ & $\begin{array}{l}2.01- \\
49.5\end{array}$ & $a, b$ \\
\hline $\begin{array}{l}S . \\
\text { isoetifolium }\end{array}$ & Palk bay, TN & 3.28 & $\begin{array}{l}0.23- \\
0.27\end{array}$ & - & $\begin{array}{l}4.82- \\
4.92\end{array}$ & $\begin{array}{l}1.55- \\
45.5\end{array}$ & $\begin{array}{l}16.5- \\
1040\end{array}$ & 42 & $\begin{array}{l}29.4- \\
64.8\end{array}$ & $\begin{array}{l}1.22- \\
1.41\end{array}$ & $\begin{array}{l}0.61- \\
0.81\end{array}$ & $\begin{array}{l}2.01- \\
49.5\end{array}$ & $a, b$ \\
\hline $\begin{array}{l}T . \\
\text { hemprichii }\end{array}$ & Palk bay, TN & 3.21 & $\begin{array}{l}0.24- \\
0.28\end{array}$ & - & $\begin{array}{l}4.81- \\
4.92\end{array}$ & $\begin{array}{l}1.55- \\
1.68\end{array}$ & $\begin{array}{l}965- \\
1040\end{array}$ & 42 & - & $\begin{array}{l}1.22- \\
1.41\end{array}$ & $\begin{array}{l}0.61- \\
0.81\end{array}$ & $\begin{array}{l}2.01- \\
2.24\end{array}$ & $\mathrm{~d}$ \\
\hline C. serrulata & GOM, TN & $\begin{array}{l}7.66- \\
8.62\end{array}$ & $\begin{array}{l}0.23- \\
0.31\end{array}$ & - & $\begin{array}{l}4.86- \\
6.44\end{array}$ & $\begin{array}{l}1.94- \\
2.16\end{array}$ & $\begin{array}{l}1095- \\
1195\end{array}$ & $\begin{array}{l}52.95- \\
64.2\end{array}$ & - & $\begin{array}{l}1.56- \\
2.02\end{array}$ & $\begin{array}{l}0.54- \\
0.67\end{array}$ & $\begin{array}{l}1.34- \\
2.72\end{array}$ & $\mathrm{~b}$ \\
\hline E. acoroides & GOM, TN & $\begin{array}{l}7.66- \\
8.62\end{array}$ & $\begin{array}{l}0.23- \\
0.31\end{array}$ & - & $\begin{array}{l}4.86- \\
6.44\end{array}$ & $\begin{array}{l}1.94- \\
2.16\end{array}$ & $\begin{array}{l}1095- \\
1195\end{array}$ & $\begin{array}{l}52.95- \\
64.2\end{array}$ & - & $\begin{array}{l}1.56- \\
2.02\end{array}$ & $\begin{array}{l}0.54- \\
0.67\end{array}$ & $\begin{array}{l}1.34- \\
2.72\end{array}$ & $\mathrm{~b}$ \\
\hline $\begin{array}{l}S . \\
\text { isoetifolium }\end{array}$ & GOM, TN & $\begin{array}{l}7.66- \\
8.62\end{array}$ & $\begin{array}{l}0.23- \\
0.31\end{array}$ & - & $\begin{array}{l}4.86- \\
6.44\end{array}$ & $\begin{array}{l}1.94- \\
2.16\end{array}$ & $\begin{array}{l}1095- \\
1195\end{array}$ & $\begin{array}{l}52.95- \\
64.2\end{array}$ & - & $\begin{array}{l}1.56- \\
2.02\end{array}$ & $\begin{array}{l}0.54- \\
0.67\end{array}$ & $\begin{array}{l}1.34- \\
2.72\end{array}$ & $\mathrm{~b}$ \\
\hline Seagrass & GOM, TN & - & - & - & - & $\begin{array}{l}11.3- \\
18.2\end{array}$ & $\begin{array}{l}1756- \\
5756\end{array}$ & - & $\begin{array}{l}52.1- \\
128\end{array}$ & - & - & $\begin{array}{l}20.5- \\
30.8\end{array}$ & $\mathrm{f}$ \\
\hline H. beccarii & Goa & - & - & - & - & 26 & 37750 & 3200 & 767 & 25 & & & $\mathrm{c}$ \\
\hline H. beccarii & $\begin{array}{l}\text { Malvan, } \\
\mathrm{MH}\end{array}$ & - & - & - & - & 2 & 15750 & 1500 & 260 & 4 & - & - & $\mathrm{c}$ \\
\hline H. beccarii & Vijayagiri,MH & - & - & - & - & 83 & 73900 & 2700 & 402 & 35 & - & - & $\mathrm{c}$ \\
\hline H. beccarii & Ratnagiri, MH & - & - & - & - & 121 & 75500 & 2750 & 862 & 37 & - & - & $\mathrm{c}$ \\
\hline C. rotundata & LK & - & - & - & - & - & - & 988.3 & - & - & - & - & d \\
\hline H. ovalis & LK & - & - & - & & - & - & 986.2 & - & - & - & - & $\mathrm{d}$ \\
\hline H. uninervis & LK & - & - & - & - & - & - & 988.3 & - & - & - & - & $\mathrm{d}$ \\
\hline $\begin{array}{l}\text { S. } \\
\text { isoetifolium }\end{array}$ & LK & - & - & - & - & - & - & 988.3 & - & - & - & - & $\mathrm{d}$ \\
\hline $\begin{array}{l}T . \\
\text { hemprichii }\end{array}$ & LK & - & - & - & - & - & - & 988.3 & - & - & - & - & $\mathrm{d}$ \\
\hline Seagrass & LK & - & $\begin{array}{l}0.52- \\
5.72\end{array}$ & $\begin{array}{l}0.04- \\
0.16\end{array}$ & $2.32-12$ & $\begin{array}{l}2.76- \\
21.64\end{array}$ & $\begin{array}{l}45.76- \\
316\end{array}$ & - & $4-11.32$ & $\begin{array}{l}0.64- \\
3.08\end{array}$ & $\begin{array}{l}4.4- \\
10.36\end{array}$ & $\begin{array}{l}10.3- \\
127\end{array}$ & e \\
\hline
\end{tabular}




\begin{tabular}{|c|c|c|c|c|c|c|c|c|c|c|c|c|}
\hline$S_{f}$ & ANI & $7-21$ & $\begin{array}{l}0.69- \\
1.96\end{array}$ & $\begin{array}{l}0.82- \\
100\end{array}$ & $\begin{array}{l}5.76- \\
887\end{array}$ & $\begin{array}{l}6.64- \\
130\end{array}$ & $\begin{array}{l}508- \\
32370\end{array}$ & $\begin{array}{l}2018- \\
6204\end{array}$ & $23-940$ & $2-607$ & $10-29$ & $\begin{array}{l}10.4 \\
127\end{array}$ \\
\hline
\end{tabular}

a) Govindasamy et al. 2011, b) Baby et al. 2017, c) Jagtap, 1983, d) Jagtap and Untawale, 1984, e) Thangaradjou et al. 2014, f) Kumaresan et al. 1998, g) Nobi et al. 2010, h) Sachithanandam et al. 2020
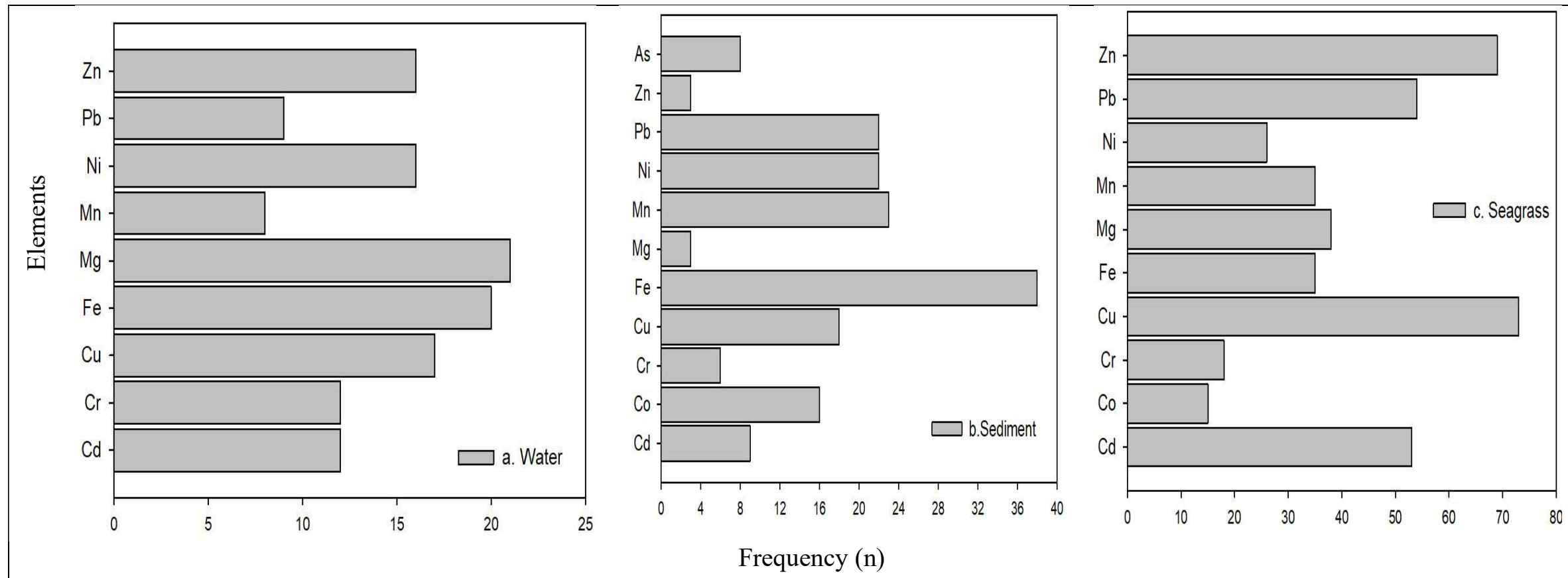

Fig.2. Frequency distribution of number of studies on various trace elements in the a) water, b) sediment and c) seagrasses from the coast of India. 


\subsection{Role of sediment characteristics in making trace elements bioavailable}

The sediment within seagrass meadows act as a storehouse of trace elements, where the influx of land run-off and anthropogenic chemicals recharge this storehouse. Other than this input, trace element recycling happens within the seagrass meadows (Sanz-Lázaro et al., 2012), which releases trace element bound to the fine grain sediment fraction of seagrass meadows. $\mathrm{pH}$ of the sediment and the overlying water plays a major role in release of this sediment bound trace metals, as low $\mathrm{pH}$ can alter the metal speciation and favor the release of metals from sediment pore waters (Atkinson et al., 2007; Simpson et al., 2005) that are generally not bioavailable. The trace metals in the water column above the sediment, are absorbed on to sediments where redox stratification of metal bound particles with depth occurs (Basallote et al., 2020, 2014; Eggleton and Thomas, 2004), until resuspension of these particles happens due to physical processes and bioturbation. Resuspension with oxygenated overlying waters results in metal speciation in the dissolved phase (Simpson et al., 2005), making the metals bioavailable in pore waters (Batley et al., 2004). Once released from pore waters into water column, these metals are bioavailable to seagrass and associated organisms till precipitation of these metals are initiated by the fine fraction ( $<63$ micron) of the sediments suspended in water column(Zoumis et al., 2001).

\subsection{TE accumulation in seagrasses}

A total of 10 trace elements are reported in seagrass tissues of India, excluding As (Fig.2c). Six seagrass species from Palk bay, seven from GOM and eight from Lakshadweep and $H$. beccarii from Goa and Maharashtra (Table 3). For trace element in seagrass, Palk bay region is the most studied region followed by Lakshadweep islands, whereas GOM and ANI have similar levels of studies (Fig.3a). In general, $S$. isoetifolium is the most studied seagrass for various trace element levels followed by C. serrulata and C. rotundata (Fig.3b). There are only 4 studies in India, which have studied trace elements in water, sediment and seagrass (Govindasamy et al., 2011; Jagtap, 1983; Jagtap and Untawale, 1984; Libin Baby, et al., 2017) and there are six studies including the above four, which have reported about trace element levels in sediment and seagrasses (Nobi et al., 2010; Vinithkumar et al., 1999) and the rest of studies have reported only about the trace elements in seagrass ecosystems, excluding the trace elements in water or sediment. 


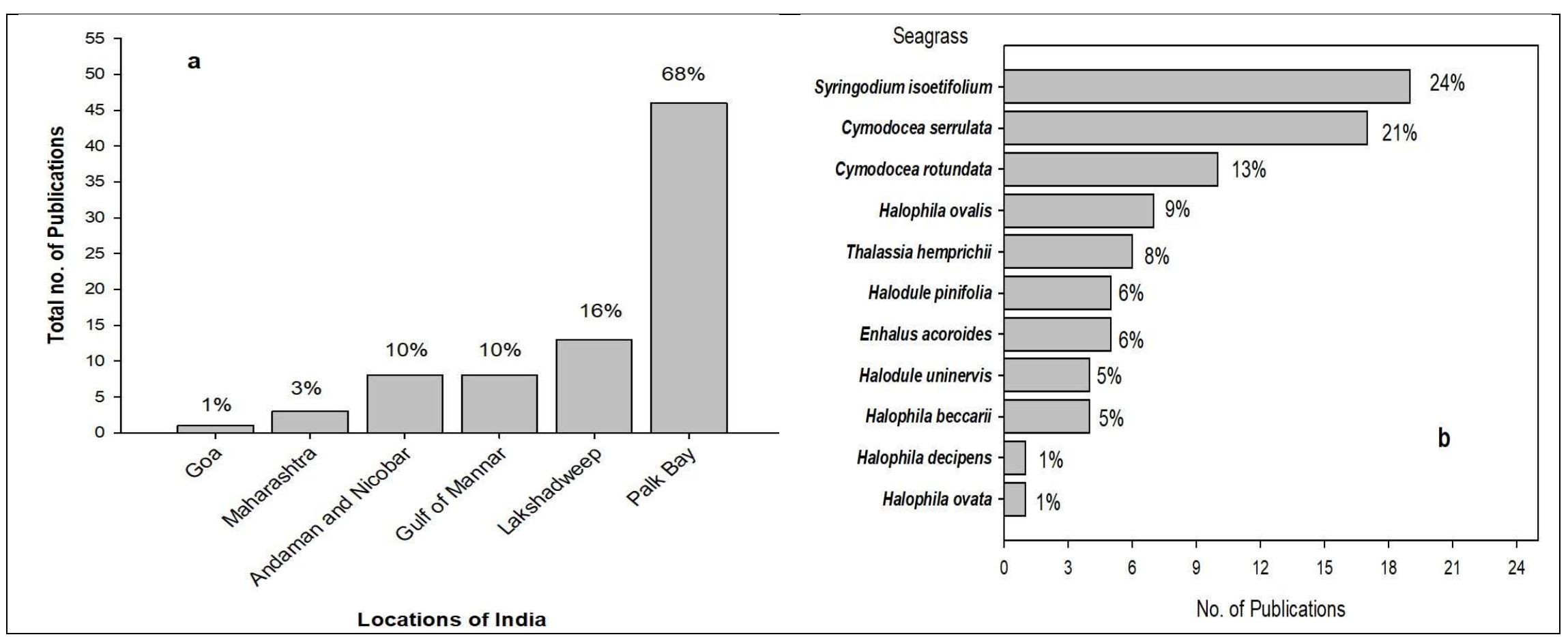

Fig.3. a) The various location of India from where seagrass studies on trace elements have been reported and b) the various seagrass species used for trace element studies. Percentage values represent the contribution of each location or seagrass to the total studies on trace elements. 
Table 3. Mean or range of trace element concentration ( $\mathrm{mg} / \mathrm{kg}$ ) in tissues of various seagrass species of India. Gulf of Mannar (GOM), Tamil Nadu (TN); Maharashtra (MH); Lakshadweep island (LK), Andaman and Nicobar Islands (ANI), Whole plant (WP), Leaves (L)

\begin{tabular}{|c|c|c|c|c|c|c|c|c|c|c|c|c|c|}
\hline \multirow[t]{2}{*}{ Seagrass } & \multirow[t]{2}{*}{ Loc. } & \multirow{2}{*}{$\begin{array}{l}\text { Tissu } \\
\text { e }\end{array}$} & \multirow[b]{2}{*}{ Cd } & \multirow[b]{2}{*}{ Co } & \multirow[b]{2}{*}{$\mathrm{Cr}$} & \multirow[b]{2}{*}{$\mathbf{C u}$} & \multicolumn{2}{|c|}{ Trace elements } & \multirow[b]{2}{*}{ Mn } & \multirow[b]{2}{*}{$\mathbf{N i}$} & \multirow[b]{2}{*}{$\mathbf{P b}$} & \multirow[b]{2}{*}{ Zn } & \multirow[t]{2}{*}{ Ref. } \\
\hline & & & & & & & $\mathbf{F e}$ & Mg & & & & & \\
\hline C. rotundata & $\begin{array}{l}\text { Palk bay, } \\
\text { TN }\end{array}$ & WP & $0.34-1.53$ & - & - & $\begin{array}{l}1.86- \\
17.35\end{array}$ & - & - & - & - & $\begin{array}{l}0.59- \\
6.14\end{array}$ & $\begin{array}{l}4.19- \\
52.66\end{array}$ & $\mathrm{i}$ \\
\hline C. serrulata & $\begin{array}{l}\text { Palk bay, } \\
\text { TN }\end{array}$ & WP & $0.12-2.84$ & - & - & $\begin{array}{l}0.13- \\
18.59\end{array}$ & $\begin{array}{l}0.33- \\
2.85\end{array}$ & $\begin{array}{l}0.24- \\
14.38\end{array}$ & - & 0.18 & $\begin{array}{l}0.26- \\
2.88\end{array}$ & $\begin{array}{l}0.33- \\
42.03\end{array}$ & $\begin{array}{l}a, b, \\
i, j\end{array}$ \\
\hline E. acoroides & $\begin{array}{l}\text { Palk bay, } \\
\text { TN }\end{array}$ & WP & $0.22-0.31$ & & & $\begin{array}{l}3.23- \\
36.5\end{array}$ & 909 & - & 304 & - & $\begin{array}{l}1.42- \\
1.74\end{array}$ & $\begin{array}{l}13.66- \\
35\end{array}$ & $\mathrm{i}, 1$ \\
\hline H. ovalis & $\begin{array}{l}\text { Palk bay, } \\
\text { TN }\end{array}$ & WP & $0.31-0.36$ & - & - & $\begin{array}{l}3.79- \\
21.67\end{array}$ & 795 & - & 2235 & & $\begin{array}{l}0.56- \\
1.96\end{array}$ & $9.45-45$ & $\mathrm{i}, 1$ \\
\hline H. pinifolia & $\begin{array}{l}\text { Palk bay, } \\
\text { TN }\end{array}$ & WP & - & - & - & $\begin{array}{l}37- \\
60.83\end{array}$ & $\begin{array}{l}1085- \\
1886\end{array}$ & - & $\begin{array}{l}220- \\
491\end{array}$ & - & - & $\begin{array}{l}35- \\
69.17\end{array}$ & 1 \\
\hline S. isoetifolium & $\begin{array}{l}\text { Palk bay, } \\
\text { TN }\end{array}$ & WP & $0.3-2.83$ & - & - & $\begin{array}{l}0.53- \\
56.67\end{array}$ & $0.22-708$ & - & $0.3-553$ & 0.18 & $\begin{array}{l}0.26- \\
3.12\end{array}$ & $\begin{array}{l}0.15- \\
53.3\end{array}$ & $\begin{array}{l}a, g, i \\
, j\end{array}$ \\
\hline T. hemprichii & GOM, TN & $\mathrm{L}$ & 0.21 & 0.37 & 3.98 & 2.94 & 67.58 & 591 & 9.28 & 1.44 & 1.52 & 4.56 & $\mathrm{p}$ \\
\hline S. isoetifolium & GOM, TN & $\mathrm{L}$ & 0.35 & 0.43 & 3.47 & 3.18 & 82.01 & 912.73 & 14.93 & 1.44 & 2.04 & 6.54 & $\mathrm{p}$ \\
\hline S. isoetifolium & GOM, TN & WP & 0.32 & - & 0.28 & 0.75 & 1074 & 918 & - & 9.18 & 7.5 & 38.36 & $\mathrm{q}$ \\
\hline H. pinifolia & GOM, TN & $\mathrm{L}$ & 0.14 & 0.32 & 1.21 & 6.65 & 156 & 863 & 23.42 & 0.67 & 1.28 & 17.59 & $\mathrm{p}$ \\
\hline H. uninervis & GOM, TN & WP & 0.3 & - & 0.29 & 4.36 & 945 & 920 & - & 6.35 & 3.09 & 22.21 & $\mathrm{q}$ \\
\hline E. acoroides & GOM, TN & $\mathrm{L}$ & 0.12 & 0.41 & 3.87 & 3.59 & 90.45 & 732.88 & 7.17 & 1.51 & 1.44 & 5.24 & $\mathrm{p}$ \\
\hline C. serrulata & GOM, TN & $\mathrm{L}$ & 0.23 & 0.283 & 0.98 & $7.49-69$ & - & 905.57 & 12.83 & 0.41 & 0.81 & 13.57 & $\mathrm{q}$ \\
\hline C. serrulata & GOM, TN & WP & 0.30 & - & 0.28 & 7.11 & 540 & 1015 & - & 12.3 & 1.22 & 29.74 & $\mathrm{p}$ \\
\hline C. rotundata & GOM, TN & $\mathrm{L}$ & 0.26 & 0.31 & 1.47 & 7.8 & 71.22 & 91.45 & 13.46 & 0.51 & 0.82 & 13.95 & $\mathrm{p}$ \\
\hline H. beccarii & GOA & WP & - & - & - & 11 & 32562 & 9800 & 575 & 10 & - & 4 & $\mathrm{c}$ \\
\hline H. beccarii & MH & WP & - & - & - & $3-6$ & $\begin{array}{l}8650- \\
27000\end{array}$ & $\begin{array}{l}7225- \\
9400\end{array}$ & $\begin{array}{l}500- \\
560\end{array}$ & $4-6$ & - & - & $\mathrm{c}$ \\
\hline C. serrulata & LK & WP & 1.58 & 0.21 & 2.95 & 8 & 124.38 & 6000 & 54 & 2.11 & 7 & 52 & $\mathrm{n}$ \\
\hline C. rotundata & LK & & 2 & 0.2 & 5 & 4.87 & 178.9 & $\begin{array}{l}1412- \\
5123\end{array}$ & 42 & 1.91 & 5.18 & 55 & $\mathrm{f}, \mathrm{n}$ \\
\hline
\end{tabular}




\begin{tabular}{|c|c|c|c|c|c|c|c|c|c|c|c|c|c|}
\hline T. hemprichii & LK & & $0.1-1.85$ & 0.47 & 3 & $4.4-13$ & $172-221$ & $\begin{array}{l}1147- \\
6200\end{array}$ & $26-63$ & 2.35 & 12 & $0.6-30$ & $\begin{array}{l}\mathrm{d}, \mathrm{n}, \\
\mathrm{o}\end{array}$ \\
\hline S. isoetifolium & LK & WP & 2 & 0.16 & 2.95 & 5 & 224.3 & $\begin{array}{l}1279- \\
80050\end{array}$ & 78 & 2.25 & 10 & 27.36 & $\mathrm{~d}, \mathrm{n}$ \\
\hline H. pinifolia & LK & WP & 2.01 & 8.12 & 18 & 12 & 5992 & 9700 & 143.2 & 13 & 12 & 45 & $\mathrm{n}$ \\
\hline H. uninervis & LK & WP & 2.25 & 11.21 & 18.4 & 18 & 5980 & $\begin{array}{l}1330- \\
6300\end{array}$ & 160 & 8 & 23.12 & 31 & $\mathrm{n}, \mathrm{d}$ \\
\hline H. decipens & LK & WP & 2 & 10 & 19.8 & 21.57 & 5990 & 10,368 & 1024 & 19.49 & 15 & 60.96 & $\mathrm{n}$ \\
\hline H. ovalis & LK & WP & - & - & - & - & - & 1732.6 & -- & - & - & & $\mathrm{d}$ \\
\hline Seagrass & ANI & WP & $1.04-3.88$ & $\begin{array}{l}0.44- \\
2.43\end{array}$ & $\begin{array}{l}34.8- \\
138.2\end{array}$ & $\begin{array}{l}44.36- \\
86.76\end{array}$ & $\begin{array}{l}604- \\
7308\end{array}$ & $\begin{array}{l}762- \\
7468\end{array}$ & $\begin{array}{l}349- \\
1180\end{array}$ & $1.8-5$ & $\begin{array}{l}3.08- \\
6.64\end{array}$ & $\begin{array}{l}21.64- \\
48.72\end{array}$ & $\mathrm{~g}, \mathrm{~m}$ \\
\hline
\end{tabular}

a) Govindasamy et al. 2011, b) Baby et al. 2017, c) Jagtap, 1983, d) Jagtap and Untawale, 1984, f) Kumaresan et al. 1998, g) Nobi et al. 2010, i) Gopi et al. 2020, j) Sudharsan et al. 2012, 1) Kannan et al., 1992, m) Thangaradjou et al., 2010a, n)Thangaradjou et al., 2013a, o) Gopinath et al., 2011, p) Kannan et al., 2011a, q) Immaculate et al., 2018 
The accumulation capacity of trace elements in the various seagrass species are different, which is reflected by the highest concentration of each trace element observed in a different seagrass species. For example, Cd concentration were highest in the tissues of $S$. isoetifolium in Palk bay, with similar levels of $\mathrm{Cd}$ in $H$. pinifolia and H. uninervis of Lakshadweep Islands. The concentration of $\mathrm{Mg}$, were also highest in S. isoetifolium of Lakshadweep Islands (Table 3). The concentration of $\mathrm{Cu}$ in seagrasses of India were highest in $C$. serrulata, at GOM, even though the highest levels were reported from mixed seagrass species of ANI(Nobi et al., 2010; Thangaradjou et al., 2014). The H. uninervis of Lakshadweep Islands had the highest concentration of $\mathrm{Co}$, whereas $\mathrm{Cr}$ concentration were highest in $H$. decipens of Lakshadweep islands. However, the highest levels of $\mathrm{Cr}$ were reported from ANI, but the authors have not specified any seagrass species (Arumugam et al., 2013; Nobi et al., 2010; Thangaradjou et al., 2013). Other than $\mathrm{Cr}$, the concentration of $\mathrm{Ni}, \mathrm{Pb}$ and $\mathrm{Zn}$ levels in $H$. decipens were also the highest in India. The concentration of Fe was highest in the tissues of $H$. beccarii, at GOA, whereas the highest concentration of $\mathrm{Mn}$ was recorded from $\mathrm{H}$. ovalis at Palk bay (Table 3). This accumulation capacity of different seagrass species of India, clearly indicates trace element accumulation in seagrass is a species-specific phenomenon and the various seagrass species of India are potential indicators of different trace element concentration in the environment. However, regarding the kind of investigated organs/tissues of seagrass most of the trace element studies in India have used the whole seagrass plants, except Kannan et al., (2011) and Immaculate et al. (2018), who have reported trace element levels in the leaves of $C$. rotundata, $C$. serrulata, $T$. hemprichii, $S$. isoetifolium, $H$. pinifolia and E. acoroides from GOM, Tamil Nadu.

\section{Effects of trace elements on seagrass physiology}

In seagrasses the concentration of elements varies within the tissues; leaves, rhizomes and roots. Where roots accumulate the maximum concentrations and the leaves accumulates less (Bonanno and Orlando-Bonaca, 2018; Mishra et al., 2019) as higher metal concentration in leaves can lead to trace metal toxicity and damage photosynthetic apparatus of seagrass (Govers, 2014; Prange and Dennison, 2000). However, in India, trace metals and their toxicity on seagrass physiology or growth have not been reported. Globally, there are some toxicity assessment of trace elements on seagrass physiology of $C$. serrulata (Aljahdali and Alhassan, 2020; Prange and Dennison, 2000), H. ovalis (Ambo-rappe et al., 2011; Prange and Dennison, 2000), H. uninervis (Prange and Dennison, 2000) and T. hemprichii (Lei et al., 2012) which can be compared to the seagrass species of India. Trace elements such as $\mathrm{Cd}\left(10 \mathrm{mg} \mathrm{L}^{-1}\right), \mathrm{Cu}$ (1-10 $\left.\mathrm{mg} \mathrm{L}^{-1}\right), \mathrm{Pb}\left(10 \mathrm{mg} \mathrm{L}^{-1}\right)$ and $\mathrm{Zn}\left(10 \mathrm{mg} \mathrm{L}^{-1}\right)$ are toxic to C. serrulata, H. ovalis, $T$. hemprichii and H. uninervis photosynthetic apparatus; Photo System-II (PS-II). Other than damaging PS-II, $\mathrm{Cu}$ concentrations reduced leaf growth and width of $H$. ovalis and amino acid levels in C. serrulata and H. uninervis (Prange and Dennison, 2000; Ambo-Rappe et al., 2011). Zinc toxicity reduced photosynthetic pigments of $T$. hemprichii (Lei et al., 2012). The antioxidant activity of $H$. ovalis and $C$. serrulata were decreased by $\mathrm{Cd}$ and $\mathrm{Pb}$ toxicity (AmboRappe et al., 2011; Aljahdali and Alhassan, 2020).

For the above mentioned four seagrass species in India, $\mathrm{Cu}$ concentration are 6-fold and 1.7-fold higher than toxic levels in the tissues of C. serrulata and at GOM and Palk bay, Tamil Nadu (Govindasamy et al., 2013; Immaculate et al., 2018; Libin Baby et al., 2017). In Lakshadweep Islands, H. uninervis and T. hemprichii have 1.8-fold and 1.3-fold higher $\mathrm{Cu}$ levels than toxic concentrations (Gopinath et al., 2011; Thangaradjou et al., 2013; Untawale and Jagtap, 1984), whereas $H$. ovalis has 2-fold higher $\mathrm{Cu}$ levels than toxic levels at Palk bay region (Gopi et al., 2020; Kannan et al., 2011). Lead levels are 1.2-fold and 2.3-fold higher in T. hemprichii and H. uninervis at Lakshadweep islands (Jagtap and Untawale, 1984; Gopinath 
et al., 2011; Thangaradjou et al., 2013). T. hemprichii and H. uninervis have 3-fold higher $\mathrm{Zn}$ levels than toxicity levels (Jagtap and Untawale, 1984; Gopinath et al., 2011; Thangaradjou et al., 2013), whereas C. serrulata has 3 to 5-fold higher levels of $\mathrm{Zn}$ concentration which can exert toxicity on its PS-II at Palk bay and GOM, Tamil Nadu and at Lakshadweep islands (Govindasamy et al., 2011; Sudarshan et al., 2012; Thangaradjou et al., 2013; Gopi et al., 2020). Trace element levels above toxic concentration for these seagrasses clearly suggests that, these four seagrass species are under stress from metal toxicity, which needs further research and attention from the scientific community of India.

High concentration of trace elements in these seagrass species will result in trophic transfer of these elements and exert toxicity to the associated trophic assemblages (de los Santos et al., 2019; Prange and Dennison, 2000), such as gastropods, molluscs, fish and invertebrates that depend on seagrass for direct and indirect food sources (Manikandan et al., 2011). Consequently, metal toxicity can lead to seagrass population loss and die offs, which will have negative consequences on the coastal ecosystem functioning.

\section{Future scenarios and metal toxicity on seagrass}

Global changes, such as ocean acidification due to increased $\mathrm{CO}_{2}$ concentrations, and low $\mathrm{pH}$, will affect the trace metal chemistry, speciation and their bio-availability (Millero et al., 2009; Zeng et al., 2015) and can have possible negative impacts on the seagrass ecosystem. Low $\mathrm{pH}$ can increase bioavailability of trace elements bound to seagrass sediment, and even increase their concentrations as trace metal speciation in seawater is strongly dependent on seawater chemistry, with several metals known to be sensitive to speciation changes within the pH range projected for near-future (Byrne et al., 1988; Richards et al., 2011). Changes in ocean carbon chemistry may also alter the behaviour of metals bound to sediments, influencing metal fluxes from contaminated sediments(Millero et al., 2009; Zeng et al., 2015). Low pH is predicted to increase the toxic free ion concentration of metals in coastal waters by as much as $115 \%$ in the next 100 years(Lewis et al., 2016; Millero et al., 2009). Saying that most of the studies on metal concentrations has been focused on marine animals (e.g. marine invertebrates, mussels, planktons, fish larva) with very few studies on seagrass ecosystems, which needs to be addressed in India.

\section{Conclusions}

Globally, seagrasses are used as bioindicators of coastal contamination (Bonanno and OrlandoBonaca, 2018, 2017; Lewis and Richard, 2009). In India, though seagrass is found to be efficient indicators of the environmental concentration of trace elements in their tissues, they have not been used as bioindicators of coastal pollution. However, the National Action Plan for seagrass ecosystems that have been launched in 2018 (Koshy et al., 2018) plans to address these issues, and provides guidelines that will use this bioindicator potential of vast seagrass ecosystems of India to facilitate their conservation and management issues.

\section{References}

Aljahdali, M.O., Alhassan, A.B., 2020. Heavy metal accumulation and anti-oxidative feedback as a biomarker in Seagrass Cymodocea Serrulata. Sustainability (Switzerland) 12. https://doi.org/10.3390/su12072841

Ambo-rappe, R., Lajus, D.L., Schreider, M.J., 2011. Heavy metal impact on growth and leaf asymmetry of seagrass , Halophila ovalis. Environmental Chemistry 3, 149-159. 
Apte, D.A., Bhave, V., Have, A., Negate, P., Pitale, R., 2016. Ecologically Important Marine and Coastal Biodiversity Areas of Maharashtra, India. Bombay Natural History Society 36 .

Arumugam, R., Kannan, R.R.R., Saravanan, K.R., Thangaradjou, T., Anantharaman, P., 2013. Hydrographic and sediment characteristics of seagrass meadows of the Gulf of Mannar Marine Biosphere Reserve, South India. Environmental Monitoring and Assessment 185, 8411-8427. https://doi.org/10.1007/s10661-013-3183-6

Atkinson, C.A., Jolley, D.F., Simpson, S.L., 2007. Effect of overlying water pH, dissolved oxygen, salinity and sediment disturbances on metal release and sequestration from metal contaminated marine sediments. Chemosphere 69, 1428-1437. https://doi.org/10.1016/j.chemosphere.2007.04.068

Avelar, M., Bonilla-Heredia, B., Merino-Ibarra, M., Herrera-Silveira, J.A., Ramirez, J., Rosas, H., Valdespino, J., Carricart-Ganivet, J.P., Martínez, A., 2013. Iron, cadmium, and chromium in seagrass (Thalassia testudinum) from a coastal nature reserve in karstic Yucatán. Environmental Monitoring and Assessment 185, 7591-7603. https://doi.org/10.1007/s10661-013-3121-7

Basallote, M.D., Borrero-Santiago, A.R., Cánovas, C.R., Hammer, K.M., Olsen, A.J., Ardelan, M. v., 2020. Trace metal mobility in sub-seabed sediments by CO2 seepage under high-pressure conditions. Science of the Total Environment 700, 134761. https://doi.org/10.1016/j.scitotenv.2019.134761

Basallote, M.D., de Orte, M.R., DelValls, T.Á., Riba, I., 2014. Studying the Effect of CO2 Induced Acidification on Sediment Toxicity Using Acute Amphipod Toxicity Test. Environmental Science \& Technology 48, 8864-8872. https://doi.org/10.1021/es5015373

Batley, G.E., Apte, S.C., Stauber, J.L., 2004. Speciation and bioavailability of trace metals in water: Progress since 1982. Australian Journal of Chemistry 57, 903-919. https://doi.org/10.1071/CH04095

Bayyana, S., Pawar, S., Gole, S., Dudhat, S., Pande, A., Mitra, D., Johnson, J.A., Sivakumar, K., 2020. Detection and mapping of seagrass meadows at Ritchie's archipelago using Sentinel 2A satellite imagery. Current Science 118, 1275-1282. https://doi.org/10.18520/cs/v118/i8/1275-1282

Bonanno, G., Borg, J.A., 2018. Comparative analysis of trace element accumulation in seagrasses Posidonia oceanica and Cymodocea nodosa: Biomonitoring applications and legislative issues. Marine Pollution Bulletin 128, 24-31. https://doi.org/10.1016/j.marpolbul.2018.01.013

Bonanno, G., di Martino, V., 2017. Trace element compartmentation in the seagrass Posidonia oceanica and biomonitoring applications. Marine Pollution Bulletin 116, 196203. https://doi.org/10.1016/j.marpolbul.2016.12.081

Bonanno, G., di Martino, V., 2016. Seagrass Cymodocea nodosa as a trace element biomonitor: Bioaccumulation patterns and biomonitoring uses. Journal of Geochemical Exploration 169, 43-49. https://doi.org/10.1016/j.gexplo.2016.07.010

Bonanno, G., Orlando-Bonaca, M., 2018. Trace elements in Mediterranean seagrasses and macroalgae. A review. Science of the Total Environment 618, 1152-1159. https://doi.org/10.1016/j.scitotenv.2017.09.192 
Bonanno, G., Orlando-Bonaca, M., 2017. Trace elements in Mediterranean seagrasses: Accumulation, tolerance and biomonitoring. A review. Marine Pollution Bulletin 125, 8-18. https://doi.org/10.1016/j.marpolbul.2017.10.078

Bonanno, G., Raccuia, S.A., 2018. Comparative assessment of trace element accumulation and bioindication in seagrasses Posidonia oceanica, Cymodocea nodosa and Halophila stipulacea. Marine Pollution Bulletin 131, 260-266. https://doi.org/10.1016/j.marpolbul.2018.04.039

Byrne, R.H., Kump, L.R., Cantrell, K.J., 1988. The influence of temperature and $\mathrm{pH}$ on trace metal speciation in seawater. Marine Chemistry 25, 163-181. https://doi.org/10.1016/0304-4203(88)90062-X

Costanza, R., de Groot, R., Braat, L., Kubiszewski, I., Fioramonti, L., Sutton, P., Farber, S., Grasso, M., 2017. Twenty years of ecosystem services: How far have we come and how far do we still need to go? Ecosystem Services 28, 1-16.

https://doi.org/10.1016/j.ecoser.2017.09.008

de los Santos, C.B., Arenas, F., Neuparth, T., Santos, M.M., 2019. Interaction of short-term copper pollution and ocean acidification in seagrass ecosystems: Toxicity, bioconcentration and dietary transfer. Marine Pollution Bulletin 142, 155-163. https://doi.org/10.1016/j.marpolbul.2019.03.034

Duarte, C.M., Kennedy, H., Marbà, N., Hendriks, I., 2013. Assessing the capacity of seagrass meadows for carbon burial: Current limitations and future strategies. Ocean and Coastal Management 83, 32-38. https://doi.org/10.1016/j.ocecoaman.2011.09.001

Eggleton, J., Thomas, K. v., 2004. A review of factors affecting the release and bioavailability of contaminants during sediment disturbance events. Environment International 30, 973-980. https://doi.org/10.1016/j.envint.2004.03.001

Fortes, M.D., 2018. Seagrass ecosystem conservation in Southeast Asia needs to link science to policy and practice. Ocean and Coastal Management 159, 51-56. https://doi.org/10.1016/j.ocecoaman.2018.01.028

Geevarghese, G.A., Akhil, B., Magesh, G., Krishnan, P., Purvaja, R., Ramesh, R., 2018. A comprehensive geospatial assessment of seagrass distribution in India. Ocean and Coastal Management 159, 16-25. https://doi.org/10.1016/j.ocecoaman.2017.10.032

Gillis, L.G., Jones, C.G., Ziegler, A.D., van der Wal, D., Breckwoldt, A., Bouma, T.J., 2017. Opportunities for protecting and restoring tropical coastal ecosystems by utilizing a physical connectivity approach. Frontiers in Marine Science 4, 374. https://doi.org/10.3389/fmars.2017.00374

Gopi, S., Arulkumar, A., Ganeshkumar, A., Rajaram, R., Miranda, J.M., Paramasivam, S., 2020. Heavy metals accumulation in seagrasses collected from Palk Bay, South-eastern India. Marine Pollution Bulletin 157, 111305. https://doi.org/10.1016/j.marpolbul.2020.111305

Gopinath, A., Muraleedharan, N.S., Chandramohanakumar, N., Jayalakshmi, K. v., 2011. Statistical significance of biomonitoring of marine algae for trace metal levels in a coral environment. Environmental Forensics 12, 98-105.

https://doi.org/10.1080/15275922.2011.547440 
Govers, L.L., 2014. The effects of biogeochemical stressors on seagrass ecosystems The effects of biogeochemical stressors on seagrass ecosystems.

Govindasamy, C., Anantharaj, K., Srinivasan, R., 2013. Seasonal variations in seagrass biomass and productivity in Palk Bay, Bay of Bengal, India. https://doi.org/10.5897/IJBC12.132

Govindasamy, C., Arulpriya, M., 2011. Seasonal variation in seagrass biomass in Northern Palk Bay, India. Biodiversity 12, 223-231. https://doi.org/10.1080/14888386.2011.653542

Govindasamy, C., Arulpriya, M., Ruban, P., L, F.J., Ilayaraja, A., 2011. Concentration of heavy metals in Seagrasses tissue of the Palk Strait, Bay of Bengal. International Journal of Environmental Sciences 2, 145-153. https://doi.org/10.6088/ijes.00202010016

Govindasamy, C., Azariah, J., 1999. Seasonal variation of heavy metals in coastal water of the Coromandel coast, Bay of Bengal, India. Indian Journal of Marine Sciences 28, 249256.

Guannel, G., Arkema, K., Ruggiero, P., Verutes, G., 2016. The Power of Three : Coral Reefs , Seagrasses and Mangroves Protect Coastal Regions and Increase Their Resilience. PLoS ONE 11, e0158094. https://doi.org/10.1371/journal.pone.0158094

Hemminga, M.A., and Duarte, C.M., 2002. Seagrass Ecology, Limnology and Oceanography. Cambridge University Press.

Immaculate, TT, L., Patterson, J., 2018. Macro and micro nutrients of seagrass species from Gulf of Mannar, India. MOJ Food Processing \& Technology 6, 391-398. https://doi.org/10.15406/mojfpt.2018.06.00193

Jagtap, T.G., 1983. Metal Distribution in Halophila beccarii (Aschers) and sourrounding environment along the central west coast of India.pdf. Oceanography 16, 429-434.

Jagtap, T.G., Komarpant, D.S., Rodrigues, R.S., 2003. Status of a seagrass ecosystem: An ecologically sensitive wetland habitat from India. Wetlands 23, 161-170. https://doi.org/10.1672/0277-5212(2003)023[0161:SOASEA]2.0.CO;2

Jagtap,TG and Untawale, A., 1984. Chemical composition of marine macrophytes and their surrounding water and sediments, from Minicoy, Lakshadweep. Indian Journal of Marine Sciences 13, 123-125.

Kannan, R., Ganesan, M., Govindasamy, C., Rajendran, K., Sampathkumar, P., Kannan, L., 2011. Tissue concentration of heavy metals in seagrasses of the Palk Bay, Bay of Bengal. International Journal of Environmental Sciences 2, 145-153.

Koshy, N.E., Bhatt, J.R., Vakily, J.M., 2018. Synthesis of the Conference on Management and Conservation of Seagrass Ecosystems in India. Ocean and Coastal Management 159, 3-6. https://doi.org/10.1016/j.ocecoaman.2017.11.001

Lei, L.I., Xiaoping, H., Borthakur, D., Hui, N.I., 2012. Photosynthetic activity and antioxidative response of seagrass $\mathrm{T}$ halassia hemprichii to trace metal stress. Acta Oceanologica Sinica 31, 98-108. https://doi.org/10.1007/s13131-012-0210-3 
Lewis, C., Ellis, R.P., Verno, E., Elliot, K., Newbatt, S., Wilson, R.W., 2016. Ocean acidification increases copper toxicity differentially in two key marine invertebrates with distinct acid-base responses 1-10. https://doi.org/10.1038/srep21554

Lewis, M.A., Richard, D., 2009. Nonnutrient anthropogenic chemicals in seagrass ecosystems: Fate and effects. Environmental Toxicology and Chemistry 28, 644-661. https://doi.org/10.1897/08-201.1

Libin Baby, Gireesh Kumar TR, Remyakumari KR, J.V., Sankar TV and Chandramohanakumar N, 2017. Comparison of hydrographic and sediment characteristics of seagrass meadows of Gulf of Mannar and Palk Bay, South West Coast of India. International Journal of Fisheries and Aquatic Studies 5, 80-84.

Machowski, R., Rzetala, M.A., Rzetala, M., Solarski, M., 2019. Anthropogenic enrichment of the chemical composition of bottom sediments of water bodies in the neighborhood of a non-ferrous metal smelter (Silesian Upland, Southern Poland). Scientific Reports 9, 113. https://doi.org/10.1038/s41598-019-51027-w

Manikandan, S., Ganesapandian, S., Singh, M., Kumaraguru, A.K., 2011. Distribution and Spatial variation of seagrass in the northern part of Gulf of Mannar, Southeastern India. Asian Journal of Plant Sciences 10, 80-85. https://doi.org/10.3923/ajps.2011.80.85

McKenzie, N., 2020. The global distribution of seagrass meadows. Environmental Research Letters.

Medina-Gomez, I., 2016. Response of Thalassia Testudinum Morphometry and Distribution to Environmental Drivers in a Pristine Tropical Lagoon. PLoS ONE 2007, 1-24. https://doi.org/10.1371/journal.pone.0164014

Millero, F., Woosley, R., DiTrolio, B., Waters, J., 2009. Effect of Ocean Acidification on the Speciation of Metals in Seawater. Oceanography. https://doi.org/10.5670/oceanog.2009.98

Mishra, A., Apte, D., 2020. Ecological connectivity with mangroves influences tropical seagrass population longevity and meadow traits within an island ecosystem. Marine Ecology Progress Series 644, 47-63. https://doi.org/10.3354/meps13349

Mishra, A.K., Kumar, M., 2020. Andaman mangrove sediments : source of nutrients and sink of heavy metals. Indian Journal of Geo Marine Sciences 49, 156-166. https://doi.org/10.1101/431262

Mishra, A.K., Mohanraju, R., 2018. Epiphytic Bacterial Communities in Seagrass Meadows of Oligotrophic Waters of Andaman Sea. OALib 05, 1-12. https://doi.org/10.4236/oalib.1104388

Mishra, A.K., Santos, R., Hall -Spencer, J.M., 2019. Elevated trace elements in sediments and seagrasses at CO2 seeps. Marine Environmental Research 104810. https://doi.org/10.1016/j.marenvres.2019.104810

Nobi, E.P., Dilipan, E., Thangaradjou, T., Sivakumar, K., Kannan, L., 2010. Geochemical and geo-statistical assessment of heavy metal concentration in the sediments of different coastal ecosystems of Andaman Islands, India. Estuarine, Coastal and Shelf Science 87, 253-264. https://doi.org/10.1016/j.ecss.2009.12.019 
Nordlund, L.M., Unsworth, R.K.F., Gullström, M., Cullen-Unsworth, L.C., 2018. Global significance of seagrass fishery activity. Fish and Fisheries 19, 399-412. https://doi.org/10.1111/faf.12259

Ondiviela, B., Losada, I.J., Lara, J.L., Maza, M., Galván, C., Bouma, T.J., van Belzen, J., 2014. The role of seagrasses in coastal protection in a changing climate. Coastal Engineering 87, 158-168. https://doi.org/10.1016/j.coastaleng.2013.11.005

Parthasarathy, N., Ravikumar, K., Ganesan, R., Ramamurthy, K., 1991. Distribution of seagrasses along the coast of Tamil Nadu, southern India. Aquatic Botany 40, 145-153. https://doi.org/10.1016/0304-3770(91)90092-J

Patankar, V., Wagh, T., Tyabji, Z., 2018. Observations on the female flowers and fruiting of tape grass Enhalus acoroides from South Andaman Islands, India. Journal of Threatened Taxa 10, 11391-11398. https://doi.org/10.11609/jott.3138.10.1.11126-11146

Patro, Shesdev, Krishnan, P., Deepak Samuel, V., Purvaja, R., Ramesh, R., 2017. Seagrass and saltmarsh ecosystems in South Asia: An overview of Diversity, Distribution, Threats and Conservation. Wetland Science: Perspectives From South Asia 1-587. https://doi.org/10.1007/978-81-322-3715-0

Potouroglou, M., Bull, J.C., Krauss, K.W., Kennedy, H.A., Fusi, M., Daffonchio, D., Mangora, M.M., Githaiga, M.N., Diele, K., Huxham, M., 2017. Measuring the role of seagrasses in regulating sediment surface elevation. Scientific Reports 7, 1-11. https://doi.org/10.1038/s41598-017-12354-y

Prange, J. a., Dennison, W.C., 2000. Physiological responses of five seagrass species to trace metals. Marine Pollution Bulletin 41, 327-336. https://doi.org/10.1016/S0025326X(00)00126-0

Prathep, A., Carpenter, K.E., Erftemeijer, P.L.A., Calumpong, H.P., Orth, R.J., Waycott, M., Coles, R.G., Dennison, W.C., Tussenbroek, B. van, Bujang, J.S., la Nafie, Y.A., Short, F.T., Nasution, I.M., Fortes, M.D., Polidoro, B., Livingstone, S.R., Judson Kenworthy, W., Freeman, A.S., Jagtap, T.G., Carruthers, T.J.B., Bandeira, S., Zieman, J.C., Kamal, A.H.M., Kendrick, G.A., Vergara, S.G., Sanciangco, J.C., 2011. Extinction risk assessment of the world's seagrass species. Biological Conservation 144, 1961-1971. https://doi.org/10.1016/j.biocon.2011.04.010

Richards, R., Chaloupka, M., Sanò, M., Tomlinson, R., 2011. Modelling the effects of "coastal" acidification on copper speciation. Ecological Modelling 222, 3559-3567. https://doi.org/10.1016/j.ecolmodel.2011.08.017

Richir, J., 2016. Trace Elements in Marine Environments: Occurrence, Threats and Monitoring with Special Focus on the Coastal Mediterranean. Journal of Environmental \& Analytical Toxicology 06, 1-19. https://doi.org/10.4172/2161-0525.1000349

Richir, J., Gobert, S., 2014. A reassessment of the use of Posidonia oceanica and Mytilus galloprovincialis to biomonitor the coastal pollution of trace elements: New tools and tips. Marine Pollution Bulletin 89, 390-406.

https://doi.org/10.1016/j.marpolbul.2014.08.030

Roberts, D. a., Johnston, E.L., Poore, A.G.B., 2008. Contamination of marine biogenic habitats and effects upon associated epifauna. Marine Pollution Bulletin 56, 1057-1065. https://doi.org/10.1016/j.marpolbul.2008.03.003 
Sachithanandam, V., Parthasarathy, P., Sai Elangovan, S., Kasilingam, K., Dhivya, P., Mageswaran, T., Mohan, P.M., 2020. A baseline study on trace metals concentration and its ecological risk assessment from the coast of South Andaman Island, India. Regional Studies in Marine Science 36, 101242. https://doi.org/10.1016/j.rsma.2020.101242

Sanz-Lázaro, C., Malea, P., Apostolaki, E.T., Kalantzi, I., Marín, a., Karakassis, I., 2012. The role of the seagrass Posidonia oceanica in the cycling of trace elements. Biogeosciences 9, 2497-2507. https://doi.org/10.5194/bg-9-2497-2012

Serrano, O., Mateo, M.A., Dueñas-Bohórquez, A., Renom, P., López-Sáez, J.A., Martínez Cortizas, A., 2011. The Posidonia oceanica marine sedimentary record: A Holocene archive of heavy metal pollution. Science of the Total Environment 409, 4831-4840. https://doi.org/10.1016/j.scitotenv.2011.08.001

Simpson, B.S.L., Batley, G.E., Chariton, A. a, Stauber, J.L., King, C.K., Chapman, J.C., Hyne, R. v, Gale, S. a, Roach, A.C., Maher, W. a, Simpson, S.L., 2005. Handbook for Sediment Quality Assessment Quality Assessment. Design 126.

Stockdale, A., Tipping, E., Lofts, S., Mortimer, R.J.G., 2016. Effect of Ocean Acidification on Organic and Inorganic Speciation of Trace Metals. Environmental Science and Technology 50, 1906-1913. https://doi.org/10.1021/acs.est.5b05624

Sudharsan, S., Seedevi, P., Ramasamy, P., Subhapradha, N., Vairamani, S., Shanmugam, A., 2012a. Heavy metal accumulation in seaweeds and sea grasses along southeast coast of India. Journal of Chemical and Pharmaceutical Research 4, 4240-4244.

Sudharsan, S., Seedevi, P., Ramasamy, P., Subhapradha, N., Vairamani, S., Shanmugam, A., 2012b. Heavy metal accumulation in seaweeds and sea grasses along southeast coast of India. Journal of Chemical and Pharmaceutical Research 4, 4240-4244.

Thangaradjou, T., Bhatt, J.R., 2018. Status of seagrass ecosystems in India. Ocean and Coastal Management 159, 7-15. https://doi.org/10.1016/j.ocecoaman.2017.11.025

Thangaradjou, T., Nobi, E.P., Change, C., Sivakumar, K., 2009. Seagrass-Watch The official magazine of the Seagrass-Watch global assessment and monitoring program $\mathrm{C}$ oastal Canaries. Seagrass Watch.

Thangaradjou, T., Raja, S., Subhashini, P., Nobi, E.P., Dilipan, E., 2013. Heavy metal enrichment in the seagrasses of Lakshadweep group of islands - A multivariate statistical analysis. Environmental Monitoring and Assessment 185, 673-685. https://doi.org/10.1007/s10661-012-2583-3

Thangaradjou, T., Subhashini, P., Raja, S., Dilipan, E., Nobi, E.P., 2014. Evidences for heavy metal contamination in surface sediments of seagrass ecosystem of Lakshadweep archipelago, India. Environmental Earth Sciences 71, 1135-1146. https://doi.org/10.1007/s12665-013-2517-6

Tripathy, G.R., Singh, S.K., Ramaswamy, V., 2014. Major and trace element geochemistry of Bay of Bengal sediments: Implications to provenances and their controlling factors. Palaeogeography, Palaeoclimatology, Palaeoecology 397, 20-30. https://doi.org/10.1016/j.palaeo.2013.04.012

Unsworth, R.K.F., Cullen-unsworth, L.C., 2018. A call for seagrass protection. science.org. https://doi.org/10.1126/science.aat7318 
Unsworth, R.K.F., Gullström, M., Cullen-unsworth, L.C., 2017. Global significance of seagrass fishery activity. https://doi.org/10.1111/faf.12259

Untawale, A.G., Jagtap, T.G., 1984. Marine macrophytes of minicoy (Lakshadweep) coral atoll of the Arabian Sea. Aquatic Botany 19, 97-103. https://doi.org/10.1016/03043770(84)90010-X

Usero, J., Morillo, J., Gracia, I., 2005. Heavy metal concentrations in molluscs from the Atlantic coast of southern Spain. Chemosphere 59, 1175-1181. https://doi.org/10.1016/j.chemosphere.2004.11.089

Vinithkumar, N. v., Kumaresan, S., Manjusha, M., Balasubramanian, T., 1999. Organic matter, nutrients and major ions in the sediments of coral reefs and seagrass beds of Gulf of Mannar biosphere reserve, southeast coast of India. Indian Journal of Marine Sciences 28, 383-393.

Vizzini, Salvatrice, Costa, V., Tramati, C., Gianguzza, P., Mazzola, A., 2013. Trophic transfer of trace elements in an isotopically constructed food chain from a semi-enclosed marine coastal area (Stagnone di Marsala, Sicily, Mediterranean). Archives of Environmental Contamination and Toxicology 65, 642-653.

https://doi.org/10.1007/s00244-013-9933-1

Vizzini, S., di Leonardo, R., Costa, V., Tramati, C.D., Luzzu, F., Mazzola, a., 2013. Trace element bias in the use of $\mathrm{CO} 2$ vents as analogues for low $\mathrm{pH}$ environments: Implications for contamination levels in acidified oceans. Estuarine, Coastal and Shelf Science 134, 19-30. https://doi.org/10.1016/j.ecss.2013.09.015

Waycott, M., Duarte, C.M., Carruthers, T.J.B., Orth, R.J., Dennison, W.C., Olyarnik, S., Calladine, A., Fourqurean, J.W., Heck, K.L., Hughes, A.R., Kendrick, G.A., Kenworthy, W.J., Short, F.T., Williams, S.L., 2009. Accelerating loss of seagrasses across the globe threatens coastal ecosystems. Proceedings of the National Academy of Sciences 106, 12377-12381. https://doi.org/10.1073/pnas.0905620106

Yang, J., Ye, Z., 2009. Metal accumulation and tolerance in wetland plants. Frontiers of Biology in China 4, 282-288. https://doi.org/10.1007/s11515-009-0024-7

Zeng, X., Chen, X., Zhuang, J., 2015. The positive relationship between ocean acidification and pollution. Marine Pollution Bulletin 91, 14-21. https://doi.org/10.1016/j.marpolbul.2014.12.001

Zoumis, T., Schmidt, A., Grigorova, L., Calmano, W., 2001. Contaminants in sediments: remobilisation and demobilisation. Science of the Total Environment 266, 195-202. https://doi.org/10.1016/S0048-9697(00)00740-3 